\title{
Kalkınma Antropolojisinin Kuramsal Eleştirisi
}



\section{Theoretical Critique of Developmental Anthropology}

Abstract

In this study, the character and content of sustainable development approach and the relation between anthropology and sustainable development approach were discussed. Moreover, the ways of how the theoretical background should be is considered by evaluating the implemented national and international projects from an anthropological viewpoint. In this context, the impact of development rhetoric with its historical and social change on societies or communities and its analysis in modernization and industrialization processes, and the comparative examination of development practices were examined as one of the basic issues of anthropology.

Key Words: Sustainable development, development anthropology, applied anthropology

sürdürülebilir kalkınma kavramını gündelik yaşamın bir parçası haline getirmekle kalmamış, katılımcı mekanizmaların ve süreçlerin önce Birleşmiş Milletler'ce, ardından da tüm hükümetler ve diğer kurum ve kuruluşlarca benimsenmesini ya da en azından dikkate alınmasını sağlamıştır. 1987'de başlayan sürdürülebilir kalkınmanın içeriğinin belirlenmesi ve sınırlarının çizilmesi tartışmasına antropologlar da katılma ihtiyacı duymuşlardır. Kalkınmanın ölçütlerini ekonomik verilerin ötesine taşıyıp sadece çevreyi korumayı değil aynı zamanda sosyal adalet hedeflerini de hesaba kattığını iddia eden sürdürülebilirlik kavramı çoğu yönden antropoloji için ilgilenilmesi gereken bir yaklaşım olarak görülmüştür (Bates, 1996; Kottak, 2004.

$\mathrm{Bu}$ anlamda sürdürülebilirlik kavramının, az gelişmiş ya da gelişmekte olan ülkelerde toplumların ya da toplulukların geleceğini etkileyebilecek alternatif kalkınma senaryolarını değerlendirmek için antropologlara uygun bir çerçeve sunabileceği düşünülmüştür. Örneğin Kottak'a (2004) göre, terim bugünkü içeriği itibariyle çoğu zaman antropologlarca anlaşılmaz olarak kalmaktadır. Antropologların birçoğu sosyal kurumlar ve çevreyle bağlantıll insan davranışları da dâhil ilgili konular üzerinde çalışmasına karşın,

Dünya Cevre Hareketi açısından bir dönüm noktası niteliğini taşıyan Rio Konferansı, yalnızca 
sürdürülebilirlik kavramı doğrudan antropolojik bir bakışla bağlantısı olmayan bir kavram gibi görülmektedir.

\section{Kalkınma Antropolojisi}

Sanayileşme, modernleşme ve kalkınma, sosyal değişme tartışmalarında en çok kullanılan kavramlardır. İkinci Dünya Savaşı'na kadar geçen süre içerisinde sosyal bilimcilerin birçoğu Avrupa ülkelerinin maruz kaldığ1 sosyal, iktisadi, siyasi değişimleri tanımlamak amacıyla bu kavramları aynı anlama gelen ya da birbirlerini tamamlayan ana kavramlar olarak kullanmışlardır. Özellikle uygulamalı sosyoloji ve antropoloji alanları açısından bakıldığında, sanayileşme, Avrupa ülkelerinin yakın tarihlerinde tanık olunan teknik ve iktisadi değişmeyi, modernleşme ise sosyal ve siyasi değişmeyi içeren süreçler olarak görülürken; kalkınma ise bu iki süreci bir arada barındıran bir olgu olarak kabul edilmiştir (Bendix, 1995; Arce ve Long, 2000).

Bilindiği gibi antropoloji, özü itibariyle Bat1 merkezli düşünce ve yaşam biçim(ler)inden uzak ya da diğer bir deyişle farklı olduğu kabul edilen ve yine "Batı" tarafindan öteki olarak konumlandırılmış toplumların ya da toplulukların incelenmesi ekseninde ortaya çıkmış bir bilim dalıdır. $\mathrm{Bu}$ anlamda, politik-ideolojik düzlemde Batı ya da Avrupa merkezli düşünce sisteminin "öteki” uygarlıklara iletilmesi, ötekinin deşifre edilerek dönüştürülmesi ve bu vesileyle Doğu'daki Batı'nın yaratılması fikrine uzun yillar hizmet etmiştir (Escobar, 1995). İlkel, geri kalmış toplulukların yaşam biçimlerinin, inanç sistemlerinin, iktisadi faaliyetlerinin, kısaca sosyal, iktisadi, ahlaki, politik durumlarının gözlenmesi, alan araştırması bağlamında antropolojinin ana gövdesini oluşturmuştur. Morgan, Malinowski, Benedict gibi antropologların çalışmalarında da açıkça görülebileceği gibi "ilkel" ve "modern" toplumlar arasindaki farkllikların belirlenmesi, bu farklılıkların nedenlerinin irdelenmesi ve ötekinin sinıflandırılması temelli alan araştırması pratiği, modernist, ilerlemeci ve tahakkümcü Yirminci Yüzyll sistematiğini gözler önüne sermiştir (Barret, 1996). Geri kalmış ve ilkel olana merak, onun değiştirilip modernleştirilmesi arzusu antropolojinin alt alanlarından en önemlisi olan uygulamalı antropolojinin merkezine oturmuştur.

Soğuk Savaş y1lları olarak görülen İkinci Dünya Savaşı ile Berlin Duvarı'nın yıkılması arasında geçen süre boyunca Batı merkezli düşünce sistemine dayalı ilerlemeci ve kalkınmacı yaklaşımların geri kalmış topluluklar ya da toplumlar üzerindeki yetersiz kalan etkileri sosyal bilimlerde farklı yaklaşım arayışlarını da beraberinde getirmiştir. 1960'ların sonu, 1970’lerin başlarında Batılı toplum ve insan bilimleri, 1950'lerin ortalarından bu yana gerçek yaşamda olagelen değişimler ile sosyal bilimlerin bunları açıllamada içerisine düştüğü yetersizliğe ilişkin bir altüstlüğe, siyasal, kurumsal ve pratik bir krize sahne olmuştur. 1960'ların ikinci yarısından itibaren Avrupa'da ortaya çıan işçi ve öğrenci hareketleri ile beraberinde oluşan siyasi ve iktisadi değişim de sosyal bilimler açısından mevcut kuram ve yaklaşımların yeniden irdelenmesi gerektiğini göstermiştir (Özbudun ve Şafak, 2005).

1970'lerin ortalarından itibaren modernist kalkınma söyleminin çöküşü ve neoliberal politikaların güçlenmesi sosyal bilimlerde eski olguların, yaklaşım ve pratiklerin tamamıyla gözden geçirilmesi gerektiği savını güçlendirmiştir. Öyle ki, yorumsamacı (hermeneutik) ve post-yapısalc1 kuramsal çerçeveden ve neoliberal politikalardan beslenen postmodernizm, alan araştırmasına dayalı araştırma sonuçlarını edebi bir metin olarak kabul etmemiz gerektiği yollu temel saviyla antropolojiye sıçramıştır.

$\mathrm{Bu}$ çerçevede, kalkınma retoriğinin geçirdiği tarihsel ve sosyal değişimin toplumlar ya da topluluklar üzerindeki etkisinin, modernleşme ve sanayileşme süreçleri kapsamında değerlendirilmesi ve kalkınma pratiklerinin ciddi anlamda karşılaştırmalı olarak incelenmesi antropolojinin temel meselelerinden biri haline gelmiştir.

Kalkınma antropolojisi farklı disiplinlerin, özellikle iktisat ve sosyoloji bilimlerinin ekonomik ve kültürel değişim çalışmalarından hareketle, 1970'lerden itibaren yoksulluğun azaltılması, çevresel bozulma, hastalık, beslenme bozukluğu, cinsiyet eşitsizliği ve etnik çatışma konularına kuramsal ve uygulamalı bir yönelişin sonucu olarak antropolojinin bir alt dalı haline gelmiştir (Bates, 199). Antropologların kendilerini kalkınma antropologu olarak tanımlamaya başlamaları ise yaklaşık yirmi yıllık bir süreci kapsamaktadır. Devletlerarası anlaşmalarla çerçevesi çizilmiş ve dünya devletleri arasında görece sosyal ve ekonomik bir denge kurulması amaciyla meydana getirilen birlikler, fonlar ve kuruluşların uluslararası yardım çalışmaları ki bu çalışmaların üçte ikisi Afrika ülkelerini kapsamaktadır, kalkınma olgusunun antropologlar açısından ciddi bir uzmanlık alanı olarak görülmesine yol açmıştır. Özellikle SSCB ve Doğu Bloku ülkelerinin eski sistemden kopmasiyla birlikte, 1990 sonrası ortaya çıkan ve sadece söz konusu ülkeleri değil, tüm dünyayı etkileyen sosyal, ekonomik, siyasi sorunlar, yeni, hılı ve kolektif çözümlerin bulunması ve hızla uygulamaya konulması gerekliliğini doğurmuştur. Uluslararası düzeyde kurulan ve devletlerarası hukukla işleyişi sürdürülen Dünya Bankası (WB), Uluslararası Para Fonu (IMF), Uluslararas1 Finans Kurumu (IFC), Birleşmiş Milletler Kalkınma Programı (UNDP), Avrupa Birliği (AB), Avrupa İmar ve Kalkınma Bankası (EBRD) gibi birlikler, yeni Dünya tasarımının şekillenmesi için ara yollar, çözüm önerileri ya da uygulama modelleri geliştirmeye eskisinden daha detaylı olarak eğilmeye başlamışlardır. Bu kuruluşlar tarafından geliştirilen çeşitli 
kalkınma projelerinde antropologlar, gerek projelerin teknik ve kuramsal hazırlanışında gerekse de uygulama sürecinde birçok görev alma imkânı bulmuştur. Böylece hem akademik hem de mesleki uzmanlik anlamında kalkınma olgusu, farklı kalkınma modelleri ve onların pratikteki uygulamaları genelde sosyal bilimcilerin, özel de ise antropologların ilgi alanı olarak ortaya çıkmıştır.

Kalkınma olgusu ile antropoloji arasındaki ilişkinin belirgin bir zemine oturması ve kalkınma antropolojisinin ortaya çıkış1, özellikle neo-marksist kuramcıların "azgelişmişlik" eleştirileri ile doğrudan ilintilidir. Uluslararası ölçekte yoğun kentleşme ve sanayileşme süreçlerinin yerel düzeyde kalıcı kültürel değişmelere ve çatışmalara yol açması ve sosyal bilimlerin genelleyici çözümlemelerinin yeni sorunlara çözüm getirmede başarısız kaldığı yollu saptamalar antropolojinin kalkınma ile ilişkisine derinlik kazandırmıştır. Bir alt alan olarak kalkınma antropolojisi, çeşitli antropologların tutarlı bir kuramsal çatı, düşünce ya da yöntem birliği altında toplandıkları bir yapı oluşturamasa da konuyla ilgilenen antropologların tercihleri doğrultusunda yürüttükleri projeler, sahip oldukları ön kabuller ve politik açılımlarla sosyal/kültürel antropoloji alanında kendisine özgü bir yer edinebilmiştir. Buna karşın kalkınma antropolojisinin ayrı bir alan ya da değer olarak kabul edilip edilemeyeceğine ilişkin birçok tartışma halen mevcuttur ve bunun da göz ard1 edilmemesi gerekmektedir (Green, 1986; Escobar, 1991).

Bugün kalkınma antropolojisi, birçok üniversitede öğretilmektedir. Birçok eserde kalkınma olgusuna antropolojik bakışın katkısı ve rolü bulunmaktadır. Özellikle 1980'lerin ortasından itibaren gelecek odaklı birçok çalışma oluşmuştur. Antropoloji ile kalkınma arasındaki sorunlu ilişki (buna etik ikilem diyebiliriz) bu eserlerin çoğunun içinde geçmektedir. Post-yapısalc1 düşünürler sanayileşme, kentleşme, modernleşme ve kalkınma söylemi üzerinde odaklanarak konuya yaklaşmayı tercih etmişlerdir ve kalkınma antropolojisinin, antropolojinin bir alt alanı olarak gelişmesine katkıda bulunmuşlardır. Güncel toplumsal, kültürel, ekonomik ve siyasi önceliklerin geçirdiği değişime uygun olarak kabuk değiştiren antropolojide kalkınmayı, "post-kalkınma" olarak kullanmayı yeğlemişlerdir (Booth, 1994; Escobar, 1995; Gardner ve Lewis, 1996; Cleveland, 2000).

Antropolojideki güçlü kuramsal, yöntemsel ve teknik çalışma ve çabalara rağmen, birçok kalkınma antropologu kapsayıcı bir antropoloji için araştırma yapmaya devam etmektedir. Söz konusu antropologlar, kuramsal etnografinin eleştirisinin öneminin farkında olurlarken, kalkınma antropolojisinin kapsayıc1 bakış açısının gözden kaçırılmaması gerektiği üzerinde durmaktadırlar. Birçok tartışma, kalkınma antropolojisinin kalkınma süreçlerinin sistemli eleştirisi, yıkıcı olanın tahlili ya da potansiyel yıkıcı müdahaleler, iç karışıklıkların ya da insanlar arasındaki sosyoekonomik farklılıkların serimlenmesi ve sürece ilişkin devam eden bir sorgulama ile bağlantılı olduğu savındadır. Örneğin, Gardner ve Lewis (1996), post-kalkınmacı mücadelede antropolojinin pozitif rolünün kalkınma söylemi ve uygulamalarını yeniden inşa etmeye çalışmak olduğunu ileri sürmektedirler.

Günümüzde antropologların enerji, inşaat ve maden alanlarında iş yapan uluslararası holdinglerin, uluslararası kalkınma modelleri üzerinde çalışan sivil toplum kuruluşlarının birçok projesinde görev aldığ1 bir gerçektir. Bölgesel ya da yerel kalkınmanın, küresel düşünüp yerel hareket etmekten geçtiği yollu temel önerme üzerine oturtulması antropolojinin hem bütünü temel alan hem de bütünü oluşturan parçaları da göz önünde tutan yaklaşımılla örtüşmektedir. Bu süreç, antropologların kalkınma program ve projelerine daha fazla katkıda bulunabilme olanağına erişmelerine olanak sağlamıştır.

Günümüzde sosyal bilimcilerin ve dolayısıyla antropologların da odaklanmak zorunda kaldıkları moda bir yaklaşım bulunmaktadır. Öyle ki, hemen hemen her toplumsal proje sürdürülebilir bir yöntem ve uygulama peşindedir. Kalkınma problemlerinin son yirmi yılda evirildiği ana dayanak noktası, kalkınmanın sürdürülebilirliği olmuştur. Böylece, küresel boyutta sürdürülebilir bir kalkınma yaratma çabası içine girilmiştir. Çevresel, sosyal, ekonomik ve yönetimsel anlamda kalkınmanın ancak sürdürülebilirliği söz konusu ise başarıya ulaşabileceği tezi öncelikli olarak sürdürülebilirlik ilkesini daha sonrasında ise kalkınmanın olmazsa olmaz yaklaşımı olan sürdürülebilir kalkınmayı üretmiştir.

\section{Kalkınma ve Sürdürülebilir Kalkınma}

Kalkınma, en basit anlamıla insan yaşamının iyileștirilmesi olarak ifade edilebilir. İktisadi anlamda kalkınma ise, bir toplumun bir aşamadan diğerine geçmesinin hedef, süreç ve şartlarının belirlendiği bir terim olarak ifade edilmektedir (Türkay, 1995).

Daha kapsamlı ifade etmek gerekirse, kalkınma kavramı bir ekonomik gelişmeye veya faaliyete atıfta bulunmadığı gibi, toplumda yaşanılan sosyal değişimlerin genel bir süreci anlamına da gelmemektedir. Çünkü ülkeler ve toplumlar her zaman bir değişim süreci içerisindedirler. Bu süreç içersinde kaynakların dağılımı, üretim teknikleri, kurumsal yapı, toplumsal değerler, insanların tutum ve davranışları değişmekte ve belirli bir yön içerisinde gelişmektedir. Ayrıca, insanların gelenekleri ve yaptıkları uğraşlar statik değildir, sürekli gelişirler ve farklı biçimler içerisinde yeniden şekillenirler. Bu yüzden kalkınma, sosyal değişim sürecini etkilemek için yapılan olumlu müdahalelerle 
yakından ilişkilidir. Kalkınma, bulunulan durumdan ya da bir önceki konumdan hareket ederek, değişime girmeyi öneren dinamik bir kavramdır. Kalkınma, üretim ve kişi başına milli gelirin artırılmasıyla birlikte, ekonomik ve sosyokültürel yapının da değiştirilmesi anlamına gelmektedir. Bir başka ifadeyle kalkınma, "bir ülkenin yapısal niteliklerinin olumlu yönde değişimidir" (Tolunay ve Akyol, 2006: 118).

Kalkınma sürecinin ekonomik, sosyal ve insani üç öğesi bulunmakta ve bunlar ülkelerin kalkınma uğraşlarında eş zamanlı olarak yürütülmektedir. Ekonomik kalkınma, insanların gereksinimi olan mal ve hizmetlerin gelişmiş bir ekonomik yap1 içerisinde üretilmesiyle, insanların refah ve mutluluğunun artması fikri üzerine inşa edilmiştir. Sosyal kalkınma ise, sosyal yaşam koşullarının iyileştirilmesi için yapılan ve ağırlıklı olarak hizmet yönü ağır basan kalkınma konularıdır. İnsani kalkınma, bireysel ve toplumsal olarak tüm insanların sahip oldukları potansiyellerini kalkınma için kullanmaları ve ülkenin olumlu yünde gelişmesinde yapıcı rol oynamalarının sağlanmasıdır (Tolunay ve Akyol, 2006).

Sürdürülebilirlik kavramının ilk olarak nerede kullanıldığını saptamak zor olmakla birlikte; eski kayıtlarda, 1713 yılında Saksonya'da sürdürülebilir ormanciliktan bahsedilmektedir. Ormancilikta ortaya çıkan bu anlayış, 18. yüzyılın sonundaki Almanya'daki bütün ormanlarda uygulanabilmesi için yasa haline dönüştürülmüştür. Sürdürülebilirlik kavramı, maksimum faydayı sürdürebilme düşüncesiyle birlikte 20. yüzyılın başlarında balıkçılığın korunmasında da kullanılmaya başlanmıştır. Genel olarak iki yüzyıldan fazla geçmişi olan sürdürülebilirlik prensibinin ormancllı ve balıkçılık dışındaki gelişimi sınırlı kalmıştır (Kılıç, 2006).

Çevre sorunlarının sınır ötesi etkileri ve küresel boyut kazanması, bu sorunların çözümünde çok yönlü iş birliğini ve uluslararası eşgüdümü ön plana çıkaran yaklaşımları gerekli kılmıştır. Özellikle, klasik kalkınma kuramlarına bağlı kalan küresel kalkınma pratiklerinin çevresel konularda yetersiz ve eksik kalması sürdürülebilir kalkınma düşüncesinin ortaya çıkmasına neden olmuştur. Çevreyle ilgili olarak uluslararası iş birliğine ilişkin ilk kapsamlı düzenlemeler 1970’li yılların başında ele alınmış ve Sürdürülebilir Kalkınma düşüncesinin ilk nüveleri ve radikal çevreci hareketlerin gayri resmi söylemler olarak ortaya çıkışları da 1970’lere rastlamıştır. Bu tarihlerde Roma Kulübü bünyesinde hazırlanan "Büyümenin Sınırları" adlı rapor gerek sürdürülebilir kalkınma gerekse derin ekoloji yaklaşımlarının ortaya çıkmasında önemli bir etkiye sahip olmuştur (Kaya ve Bıçkı, 2006).

Sürdürülebilir kalkınma yaklaşımı çerçevesinde ortaya çıkan tartışmalariseilk defa Stockholm Konferansı ile başlamış, Brundtland Raporu ile kavramsal içeriğine kavuşmuş, Rio ve Johannesburg konferanslariyla kavramın anlamı ve içeriği genişletilmiştir (Türkiye Çevre Vakfı [TÇV] 1991; World Watch Enstitüsü, 2005).

Sürdürülebilir kalkınma konusunda literatürde çok farklı tanımlara rastlanmaktadır. Bu farklılığın ortaya çıkmasının temel nedeni, sürdürülebilirliğin insan yaşamında pek çok değişikliği kapsamasıdır. Fakat, ekoloji, ekonomi ve toplum arasinda dengenin kurulmasi talebi, bütün sürdürülebilirlik araştırmalarında görülen ortak özelliktir. Hildebrandt (aktaran Kılıç, 2006: 83), bu özellikleri "insan varlı̆̆ını güvence altına almak, toplumsal üretim potansiyelini, ticaret ve kalkınma olanaklarını korumak" şeklinde özetlemektedir.

Brundlandt Komisyonu (Dünya Çevre ve Kalkınma Komisyonu olarak da anılır) sürdürülebilir kalkınmayı, gelecek nesillerin kendi gereksinimlerini karşılama becerilerini karşısına almadan, sürdürülebilir bir gelecek için üç anahtar amaçla, bugünün gereksinimlerini karşılayan kalkınma olarak tanımlamıştır. Gelişmiş dünyada yaşam kalitesi sağlayan, sosyal ve çevresel olarak yenilikçi, kaynakları verimli kullanan bir ekonomi; gelişmekte olan ülkelerde ekonomik refah ve yaşam kalitesinin iyileştirilmesi; dünya çapında bilgece kullanılan ve korunan kaynaklara sahip sağlıklı doğal bir çevre üç anahtar amacı oluşturmaktadır (Çevre Bakanlığ1, 2002; World Bank [WB], 2002).

Sürdürülebilir kalkınma, tarihsel olarak iktisadi ve ekolojik fenomenlerin bir bileşkesi olarak düşünülmelidir. Sürdürülebilir kalkınma yaklaşımının temelinde, küresel bir iktisadi kalkınmanın ancak ve ancak çevresel (ekolojik ve sosyal) dengenin korunması ile mümkün olabileceğine ilişkin düşünce yatmaktadır. Bu düşünceye varılmasında tarihsel, iktisadi, çevresel ve sosyal deneyimler rol oynamıştır.

Bu çerçevede, "sürdürülebilir kalkınma", bir yanıyla iktisadi kalkınma merkezli bir kavramdır. Diğer yandan, "iktisadi kalkınma" kavramının sanayileşme, kentleşme ve modernleşme kavramlarıyla doğrudan bir bağı vardır. $\mathrm{Bu}$ anlamda "iktisadi kalkınma" kavramının tarihsel ve kuramsal gelişiminin "sürdürülebilir kalkınma" yaklaşımının anlaşılmasında önemli bir rolü olduğu açıtır (Keleş ve Hamamc1, 2002).

Sanayi Devrimi ekonomik anlamda köklü bir değişimi temsil etmektedir. Çünkü Sanayi Devrimi ile birlikte dönemin birçok bağımsız ülkesi, devrimi gerçekleştiren İngiltere'ye göre kendi ekonomik yapısını yeniden düzenleme çabası içine girmiştir. Devrim sonrasında eskinin üretim, bölüşüm ve dağıtım biçimleri değişmek/değiştirilmek zorunda bırakılmıştır. Değişim sadece ekonomik yaşamla da sinırlı kalmamıştır. Buna sosyal ve siyasi alanlar da eşlik etmiştir. Bu nedenle, bugünün gelişmiş ülkelerinin birçoğunda olduğu gibi geri kalmış ülkelerin bir kısmında da söz konusu alanlardaki değişimin kökenlerini o tarihlere götürmek 
gerekir. Geri kalmışlıkla ilintili olarak kalkınma olgusu da Sanayi Devrimine yakın bir tarih olan 19. yüzyılın ortalarına dayanmaktadır. Bununla birlikte iktisatçıların çoğunluğu, kalkınma ekonomisinin bir alt disiplin olarak ortaya çıkışının 1930'lardaki Büyük Bunalım'la başladığını kabul etmekte ve 1939-1945 arasındaki uluslararası ekonomik sistemin çöküşünün meydana getirdiği sarsıntının kalkınma ekonomisine asıl ivmeyi kazandırdığını belirtmektedirler (Yavilioğlu, 2002).

Sanayileşme kuramları iktisadi büyümenin, ekonomik refahın tek yönlü ve çizgisel gelişimini temel almışlar, iktisadi kalkınmanın toplum refahında önemli bir rolü olduğunu dile getirmişlerdir. Fakat, İkinci Dünya Savaşı sonrası dönemde özellikle sınırları savaş sonrası belirlenmiş olan çevre (periferi) ülkeler, ekonomik anlamda bağımlılıklarını sürdürdükleri merkez ülkelerin gölgesinden kurtulmayı bir türlü başaramamışlardır. Sanayileşmesini tamamlamış ülkelerin iktisadi egemenliği, sanayileşmekte olan ülkelerin onlara yetişme çabası uğruna kendi doğal kaynaklarını tahrip etmeyi göze almalan ile doğru orantılı olarak dünyada var olan kaynakların ciddi anlamda tahribine kadar gelinmesine ${ }^{1}$ ve iktisadi anlamda küresel ve sürdürülebilir bir kalkınmanın olanaklılı̆̆ının sorgulanmasına yol açmıştır.

İktisadi kalkınma yaklaşımlarında, ekonomik büyüme merkezli ölçütlerin yerini çevresel, sosyal ve insani ölçütleri de içine alan ve sürdürülebilirliği hedefleyen ölçütlerin alması "sürdürülebilir kalkınma" yaklaşımının somutlaşmasında önemli adımlardan biridir.

Özellikle, 1960’lı yıllardan sonra kalkınma kavramının batılılaşma ve modernleşme olarak da ele alındığı görülmektedir. Bu yıllardan itibaren "kalkınma" ve "ekonomik büyüme" tabirleri büyük ölçüde eş anlamlı olarak kullanılmışlardır. Bu çerçevede kalkınma, kavram olarak teknik anlamda dinamik bir olgu olarak kabul edilmiş ve gelişmenin seviyesi ile beraber aynı zamanda gelişme sürecini de ifade etmiştir. Konuya bu açıda bakıldığında gelişmişliğin derecesinin ölçülmesi ve bu ölçüm işleminin yapılabilmesi için de belirli parametrelerin belirlenmesi gerektiği düşünülmüştür (Bendix, 1995).

Geleneksel olarak ülkelerin ve toplumların gelişmişlik dereceleri tartışıldığında ilk planda ekonomik değerler dikkate alınmaktadır. Buna karşın son yirmi yıllık süreçte, iktisadi kalkınmanın sadece ekonomik girdiler ve sayısal değerlendirmelerle ölçülemeyeceğine

\footnotetext{
${ }^{1}$ Günümüze değin ortaya konmuş kalkınma kuramlarını, Dengeli Kalkınmaya Yönelik Kuramlar, Dengesiz Kalkınmaya Yönelik Kuramlar, Doğrusal Aşamalı Kalkınma Kuramları, Neo-liberal Kuramlar, Bağımlılık Kuramları olarak sınıflandırmak mümkündür. Ayrıca, Wallerstein'ın Dünya Sisteminde semi-periferi ve özellikle periferi ülkelerin neden kalkınmada geri kaldıklarını ve başarısız olduklarını açıklayan çalısmaları da dikkate alınmalıdır (Sachs 1992; Türkay 1995).
}

ilişkin tez daha fazla taraftar toplamaya başlamıştır.

Bazı iktisatçılar, zamanımızın ekonomi anlayışının değiştiğini, bir ekonomik faaliyetin kısa dönemde kâr amacı güden bir anlayışla “sürdürülebilir" olup olmayacağ1 değerlendirmesinin yapılamayacağını, bu durumun ancak uzun dönem için söz konusu olabileceğini ciddi olarak tartışmaya açmışlardır. Bu görüşe göre, Gayri Safi Milli Hâsıla (GSMH) gibi tamamiyla ekonomik verileri temel alan hesaplamalarda ülkelerin doğal kaynaklarının kullanılmasının ve yaratılan çevre kirliliğinin söz konusu ülkelerin ekonomisine uzun dönemde getirebileceği çok önemli zararlar dikkate alınamamaktadır.

Özellikle Üçüncü Dünya ülkeleri ya da azgelişmiş ülkeler olarak adlandırılan, iktisadi kalkınmada sorunlar yaşayan ülkeler için çelişkili sonuçların ortaya çıktı̆̆ görülmüştür. $\mathrm{Bu}$ ülkeler, örneğin GSMH verilerine göre geçmişten daha iyi bir tablo sergilerken, kendi doğal çevrelerinin tahrip olmasına, bilinçsiz kaynak kullanımının yarattığ1 yoksunluğa engel olamamışlardır². Sonuçlarıdehşetvericiörneklerülkeleriniktisadikalkınma süreçlerini ölçmek için kullanılagelen tekniklerin tek yönlü ve çelişkili olduklarını da ortaya koymuştur. Bu süreçte, Birleşmiş Milletler Kalkınma Programı (UNDP) kapsamında Sürdürülebilir Ekonomik Refah Endeksi (ISEW) geliştirilmiş, düşük gelirli ülkeler için anlamlı ve faydalı bir endeks olan Kişi Başına Düşen Tahıl Tüketimi Endeksi gibi farklı endeksler de geliştirilmiştir (World Watch Enstitüsü Raporu, 1996). Sonuçta, geliştirilen ölçüt ve mekanizmalar, dünya ölçeğinde iktisadi kalkınmanın sürdürülebilir olması gerekliliğini ortaya çıkarmıştır.

Yirminci Yüzyll'ın sonunda dünya gündemine giren "sürdürülebilir kalkınma" kavramı en genel tanımıyla, gelecek kuşakların kendi ihtiyaçlarını karşılayabilme olanağından ödün vermeksizin bugünün ihtiyaçlarını karşılayabilecek kalkınma, olarak tanımlanmaktadır. Diğer bir ifadeyle, toplumun refahı için kısa, orta ve özellikle uzun vadede gerekli olan ihtiyaçların karşılanmasına yönelik ekonomik büyüme modelini tanımlamak için kullanılan bir kavramdır. Bu kavram, bugünün ihtiyaçlarının, gelecek nesillerin kendi ihtiyaçlarını yerine getirme olanağını engellemeyecek biçimde karşılanmasına yönelik kalkınma düşüncesini temel almaktadır. Uygulamada ise sürdürülebilir kalkınma, genel anlamda çevrenin korunmasına önem vermek suretiyle uzun vadeli bir ekonomik kalkınmanın koşullarını oluşturmayı öngörmektedir.

1995 yllinda Kopenhag'da gerçekleştirilen sürdürülebilir kalkınma konferans1, toplumsal

\footnotetext{
${ }^{2}$ Örneğin Nijerya, ihracat girdisinin ve Gayri Safi Milli Hâsıla’sının hesaplanmasında çok önemli bir yeri olan ormanlarının hemen hemen tamamını, on yıllık kısa bir süre içerisinde aşırı kullanımdan dolayı yitirmiş bulunmaktadır. Bir başka deyişle ülke, ekolojik bir iflasa sürüklenirken bu süre zarfında GSMH hesaplamalarında “sürdürülebilir" bir gelişme göstermiştir.
} 
dışlanmayla mücadele edilmesi ve kamu sağllğ̆ının korunmasının önemini vurgulamıştır. Amsterdam Antlaşması'yla sürdürülebilir kalkınma, Avrupa Birliği'nin hedeflerine eklenmiştir (Çevre Bakanlığı, 2002).

Birleşmiş Milletler Çevre Programı (United Nations Environment Programme - UNEP) "sürdürülebilir kalkınma" kavramını şu şekilde tanımlamıştır: "Sürdürülebilir kalkınma, insan hayatının kalitesini destekleyici ekosistemlerin taşıma kapasitelerinin kendi içerisinde geliştirilmesidir” (Clark, 1996: 23).

$\mathrm{Bu}$ süreçte, sürdürülebilir bir toplumun ise ilkeleri belirlenmiştir: yaşama sayg1 duymak, insanluğın yaşam kalitesini artırmak, yeryüzündeki yaşamın çeşitliliğini korumak, yenilenemeyen kaynakların tüketimini en aza indirmek, yeryüzünün taşıma kapasitesinin üzerine çıkmamak, alışkanlıklarımızı değiştirmek; herkesin kendi yöresine sahip çıkmasına olanak tanımak, kalkınma ve çevreyi bütüncül politikalar çerçevesinde ele almak (Clark, 1996).

Sürdürülebilir Kalkınma Yaklaşımı, iktisadi kuramların dışında, çevre merkezli kuramlarla birlikte düşünüldüğünde diğer kuramlardan daha 1lımlı bir faaliyetler zincirini kendisine ön kabul olarak almaktadır. Kalkınmanın hemen hemen tüm toplumlar için ön şart olduğu günümüzde, kalkınmanın kaynakları ve çevreyi olumsuz yönde etkilemesi, çevreyi yönetmede ve kalkınmanın kaynaklarının sürdürülebilir kılınmasında başarısız kalınması sonucu, çevre-kalkınma ilişkilerinin yeniden sorgulanmasına neden olmuştur. Bugün, kalkınmanın sağlanabilmesinin kaynakların da sürekliliğine bağlı olduğu gerçeği gerek ticari kurum ve kuruluşlar gerekse de ülke yönetimleri tarafindan yadsınamaz bir gerçek olarak görülmektedir (Akçalı, 1995; Gökday1, 1997).

\section{Antropoloji Açısından Sürdürülebilir Kalkınma Yaklaşımı}

Sürdürülebilir kalkınma yaklaşımı ile antropoloji arasındaki ilişkiyi doğrudan bir ilişki olarak gören ve kalkınma antropolojisinin güncel araştırma konularından biri olarak sürdürülebilir kalkınmayı önemseyen birçok antropolog bulunmaktadır. Örneğin, Robert W. Kates, William C. Clark, Robert Corell, J. Michael Hall ve Philip Konrad Kottak sürdürülebilir kalkınma ve antropoloji ilişkisini sürdürülebilirlik bilimi (sustainability science) kapsamında tartışmaktadırlar (Kates vd., 2001; Kottak, 2004).

Kottak'a (2004) göre, kırsal bölgelerin ve bu bölgelerde yaşayan toplulukların uzun vadeli ve karşılaştırmalı incelenmeleri yalnızca antropolojiye değil, aynı zamanda küresel süreçlerin, belli bölgelerin (örneğin, Çukurova, İskenderun Körfezi, Halfeti) ve sektörlerin (örneğin, balıkçılık, tarım, hayvancılık) çevresel ve sosyal özellikleriyle alışverişine 1şık tutmayı amaçlayan "sürdürülebilirlik bilimi”" olarak tanımlanabilecek bir disiplinler arası alana katk1 yapabilir. Ona göre, sürdürülebilirlik bilimi, adını 2002'de Güney Afrika'da düzenlenen Birleşmiş Milletler Küresel Konferansı'nın ana konusu olacak belli belirsiz alg1lanan ama yeteri kadar önemli olan sürdürülebilir kalkınma kavramından almaktadir.

Kates ve diğerlerine (2001) göre, sürdürülebilirlik bilimi, ekonomik küreselleşme gibi büyük ölçekli olaylar ve belirli çiftçilik uygulamaları gibi yerel düzeydeki olaylar arasındaki "mekân ölçekleri aralığını" genişleterek "doğa ve toplum arasındaki etkileşimi anlamayı amaçlar." Bu hedef, Elizabeth Colson, Kottak ve diğerlerinin ekonomik kalkınma çalışmaları açısından uzun süredir savunduğu "bağlantılar metodolojisi"ne (linkage methodology) çok benzemektedir. Bağlantılar metodolojisinin kökleri geçmişte yapılan antropoloji çalışmalarında yatmaktadır. Bu kökler, özellikle Julian Steward'ın büyük ölçekli evrim ve karşılaştırmalı projeleri, "genişletilmiş vaka analizi" yapan Max Gluckman ve diğerlerinin çalışmasında ve yerel kültürlerin daha büyük sistemlerle birleşikliğini vurgulayan dünya sistemi yaklaşımlarında bulunmaktadır.

Kottak'a (2004) göre, bağlantılar yaklaşımı, dünya sistemi teorisi ve diğer güncel çokuluslu ve çok mekanlı yaklaşımlarla uyuşmaktadır. Bu yaklaşımlar, bugün dünyada olup bitenin çoğunun antropolojinin yerleşik kavramsal ve metodolojik araçları, zaman çerçeveleri ve analitik birimlerinin ötesine bakmay1 gerektirdiğini vurgulamaktadirlar. Geleneksel etnografya haber kaynaklarının sınırları kaldırılan bir mekânda ne olup bittiğini bildiğini varsayıyordu. Ama bugün, aradığımız bilgiyi hiçbir grup haber kaynağı veremez. Yerel insanlar dünya sisteminin çaresiz kurbanları olmayabilir ama onları etkileyen ilişkiler ve süreçleri de tamamıyla anlayamazlar.

Kottak (2004), sürdürülebilirlik bilimini şu şekilde açıklamaktadır:

Sürdürebilirlik biliminin açıklamaya çalıştığı şeyin çoğunun bölgesel özelliği, ilgili araştırmanın, anahtar süreçlerin etkilerini yerelden küresele uzanan tam ölçek dizisiyle entegre etmek zorunda kalacağı anlamına gelmektedir. Metodolojisi de benzerdir: Sürdürülebilirlik biliminde yeni şemalar ve teknikler kullanılmalı, genişletilmeli ya da bulunmalıdır. Bunlar, kavramsal olarak daha kesin yöntemlerdeki alan çalsşmasıyla entegre uzaktan algılamay1 birleştiren gözlem yöntemleridir. Kavramsal olarak daha kesin yöntemler ise dinamik davranışın tüm sınıflarının yarı sayısal simgelenmesine dayanan mekâna bağlı yöntemlerdir. Bağlantılar araştırması çok düzeyli analiz (uluslararası, 
ulusal, bölgesel, yerel), sistem karşılaştırması ve uzun vadeli araştırmayı birleştirir. Tipik bağlantılar araştırması büyük ölçekli, görünebilir bir biçimde karşılaştırmalı grup projeleriyle ilgilenir (Kottak, 2004: 502).

Sürdürülebilirlik bilimi, kalkınma antropolojisinin kuramsal açıdan günümüz küresel ihtiyaçları dahilinde yeniden gözden geçirilmiş hali olarak, Brundlant Raporu, Gündem 21, Birleşmiş Milletler'in yayınlamış olduğu kalkınma raporları ile paralel ve karşılaştırmalı bir kalkınma anlayışına hizmet edecek şekilde tanımlanmaktadır. Bu ilişki, iki yönlüdür, denilebilir. Birleşmiş Milletler Sürdürülebilir Kalkınma Birimi, Gündem 21'de, ekonomik ve sosyal davranışın çevre üzerindeki ve çevrenin bozulmasının da yerel ve küresel ekonomiler üzerindeki etkilerini daha iyi kavramak için doğal, ekonomik ve sosyal bilimleri birleştiren yoğun bir araştırma talep etmiştir. Bu anlamda, Gündem 21'in, antropologların yıllardır araştırdığı konu olan küresel değişim karşısında insani, ekonomik ve sosyal tepkilerin araştırılmasını teşvik etmeyi amaçladığı da söylenmektedir (Kottak, 2004).

$\mathrm{Bu}$ talep ve cesaretlendirmenin ardinda disiplinler arası bir çalışmaya dayanan güçlü bir kalkınma kuramının yaratılması ve pratikte de olumlu anlamda sonuçlar yaratacak yeni bir eylem planının hazırlanması arzusu yatmaktadır. Ayrıca, şimdiye kadar bilinen kalkınma paradigmalarına yönelik eleştirilerin sosyal bilimciler ve antropologlar arasında yaygın olması, çeşitli kalkınma sektörlerinden ve değişik disiplinlerden gelen bilim adamlarının biraraya gelmesini kolaylaştırmıștır. Bu tartışmalardan, en azından aşağıdakiler konusunda şaşırtıcı şekilde düzeyli bir fikir birliği de doğmuştur:

- Ekonomik kalkınma ne uluslararası ne de ulusal boyutlarda kendiliğinden insanların yaşamını iyileştirebilir;

- Varliklı ve yoksul ülkeler küresel pazarda eşit olmayan taraflar olarak yarışırlar; eğer kalkınmakta olan ülkeler daha eşit bir konumda yarışacaklarsa insan sermayesine ve teknolojiye çok büyük yatırım yapmaları gerekecektir;

- Ne "serbest pazar" ve "bağımlılık" ne de "Marksist" kalkınma paradigmaları dünyanın en yoksul ve en yavaş gelişen ülkelerinin kalkınma gereksinimlerine yeterince yanıt verebilir;

- Dünyanın en az gelişmiş ülkelerinin çoğunun sosyo-ekonomik koşulları, geçtiğimiz yirmi yılda, önemli istisnalarla, daha kötü duruma gelmiştir;

- Dünyanın kalkınmakta olan ülkelerinin karşısına çıkan en temel problemler doğaları itibariyle sisteme bağlı olduğundan ve sisteme bağlı çözümler gerektireceğinden, kalkınmaya yönelik sektörel yaklaşımlar yetersiz kalmaktadır;

- Dünyanın kalkınmakta olan ülkelerinin karşı karşıya kaldığ1 kalkınma güçlüklerine yönelik sisteme bağlı çözümler hem kalkınma hedeflerinde hem de onların başarı yöntemlerindeki eksiklikler nedeniyle yeni düzenlemeleri gerektirir (Estes, 1993: 3-4).

$\mathrm{Bu}$ noktada, kalkınma antropolojisinin doğrudan ilgi alanına giren sürdürülebilir kalkınma yaklaşımının en azından bu ilkeler etrafinda ve pratikleri bakımından antropologlar tarafindan önemsendiği söylenebilir. Yeni sosyal, ekonomik, politik ve çevresel kalkınma paradigmalarının formüle edilmesini; kısa vadeli gelişimlerin uzun vadeli bedellerini hesaba katan, daha akılcı kalkınma yaklaşımlarının oluşturulmasını; dünyanın yenilenemeyen fiziksel kaynaklarının adil kullanımını; ekonomik, sosyal, kültürel ve fiziksel kalkınma arasında denge kurulmasını ve tüm ilgili çalışma alanlarını ve/ veya uygulayıcıları ortak bir yerel, ulusal, bölgesel ve uluslararası eylem çerçevesine taşıyan, tamamen entegre kalkınma stratejilerinin gerçekleştirilmesini talep eden sürdürülebilir kalkınma yaklaşımının antropolojik açıdan değerlendirildiği ve antropologlar tarafindan tartışmaya açıldığ1 görülmektedir (Frazier, 1997; Kates vd., 2001; Kottak, 2004).

\section{Sürdürülebilir Kalkınma Yaklaşımına Karşıt Görüşler ve Sonuç}

Sürdürülebilir kalkınma yaklaşımına en ciddi eleştiriler, genel kalkınma modellerinin eleştirisinden yola çıkarak ortaya koydukları fikirleriyle James O'Connor (1991) ve Arturo Escobar (1995)'dan gelmiştir. Kapitalist sistem içerisinde sürdürülebilirliğin mümkün olmadığ1 ve söz konusu söylemin bizzat kendisinin analiz edilmesi gerektiği eko-Sosyalist/Marksist, eko-feministbakışlarda ve derin ekoloji kuramında ön plana çıkmaktadır. Örneğin birçok Marksist düşünüre göre, sürdürülebilir kalkınmanın genel içeriği açıkça şüphelidir (örn. Barry, 2007).

Benton'a (aktaran Barry, 2007: 64) göre, 1980 ortalarında sürdürülebilir kalkınma söylemlerinin ortaya çıkması, popüler çevre hareketleri içerisindeki farklı eğilimlerin büyük ölçüde devletin maddi çıkarları tarafindan şekillenen siyasi gündemine eklemlenmesi ve meşruiyet kazanması sürecinde çok önemli bir rol oynamıştır.

Sürdürülebilir kalkınma yaklaşımı, mevcut küresel problemlere yanit mahiyetinde yeni bir olanak ya da alternatif bir model gibi takdim edilse de birçok düşünür tarafindan post-kalkınmacı bir çaba olarak görülmüştür.

Çok iyi bilindiği üzere erken modernleşme planları fakir ya da geri kalmış ülkelerin zenginleşmek 
ve kalkınmak için sanayileșmiș ülkelerin tarihsel deneyimlerini tekrar ederek zengin ve kalkınmış hale gelecekleri fikri üzerine oturmuştur. Bu fikrin oluşturmuş olduğu genel bir ekonomik, kültürel ve ideolojik şablon gelişmiş ülkelerin güdümünde gelişmekte olan ya da geri kalmış olarak kategorize edilmiş ülkelere ihraç edilmiştir. Dış kaynaklı planlama paketleri ve finansal yardımlar genel bir kalkınma şablonu çerçevesinde yapısal, kültürel ve psikolojik yaratıların meydana getirilmesi için tasarlanmışlardır (Nenda ve Warms, 2002).

Tarım ve hayvancilikta kullanilan geleneksel tekniklerin yerini endüstriyel tekniklerin alması örneğinde olduğu gibi ekonomik olarak modernleşme geleneksel geçim ekonomisinden endüstriye dayalı piyasa ekonomisine geçişi varsaymaktadır. Bu aynı zamanda, piyasa dinamiklerine uygun ürün ekimi ve yetiştiriciliği yoluyla tarıma dayalı ekonomilere sahip ülkelerin dünya piyasa ekonomisine eklemlenmelerine yol açmıştır. Ayrıca, bu süreç tarım işçiliğinden maaşlı endüstri işçiliğine geçişi de sağlamıştır.

Bu geçiş biçimi, uzun süre ekonomik kalkınmanın ve yaşamın yüksek standartlarına ulaşma çabasının bir sonucu olarak kabul edilmiştir. Kalkınmanın ciddi anlamda tek yönlü ve ekonomik bir parametre olduğu yanılg1sı, sanayileşmiş ve sanayileşmemiş toplumlar kategorisinin oluşmasina neden olmuştur. Bu başarısızlı̆̆ın ardında ise, şu anda birçok nedenin olduğu pek çok düşünür tarafindan açıkça kabul edilmektedir (Nenda ve Warms, 2002).

Klasik modernleşme kuramcıları, geri kalmış olarak sinıflandırılan toplumların geleneksel ve zamansiz bir tarih anlayışına, geçim ekonomisine dayalı fazla üretken olmayan eksik teknolojiyle iş gören üretim yöntemlerine sahip olduklarını düşünerek bu toplumların durağan kaldıklarını varsaymışlardır. Oysa zengin ulusların faaliyetlerinin dünyanın diğer yarısında fakirleşmenin yeniden üretimine katkıda bulunduğunu gözden kaçırmışlar ya da bilerek görmezden gelmişlerdir (Nenda ve Warms, 2002).

$\mathrm{Bu}$ süreçte, geri kalmış ülkelerin sanayileşmiş ülkelerin deneyimlerini takip etmelerinin imkânsız olduğu gerçeği ortaya çıkmıştır. Bunun ötesinde kalkınma projelerinin sıklıkla zayıf tasarlanmış oldukları da görülmeye başlanmıştır. Kalkınma yaklaşımlarının büyük bir kısmının teknoloji merkezli olması ve sıklıkla çevresel ve sosyal etkileri görmezden gelmeleri kalkınma modellerinin başarısız olmasına neden olmuştur (Nenda ve Warms, 2002).

Klasik modernleşme kuram ve modellerinde kendi temellerini bulan yardım projeleri ise tüm zorluklarına rağmen fakir ya da kalkınma yolunda ilerleyen ulusların yaşamlarının kalıcı bir parçası olarak görülmeye devam etmiştir. Dünya Bankası (WB) ve Birleşmiş Milletler Kalkınma Programı (UNDP) günümüzde çeşitli yardım programları ile küresel kalkınmaya katkıda bulunmak için çeşitli projelere ve programlara imza atmışlardır. Örneğin, 1995'te dünyadaki en büyük kalkınma ajanslarından biri olan Dünya Bankası yaklaşık 150 milyar dolar civarında bir fon yaratarak 1800 farklı kalkınma projesine dahil olmuştur. Uygulanan projeler sonucunda fakir ülkelerde ortalama yaşam süresi $\% 20$ ve okuma-yazma oran1 $\% 25$ yükselmiştir. Beş yaşın altındaki çocuk ölümlerinde ise yarı yarıya azalma sağlanmıştır (Nenda ve Warms, 2002).

Buradaki önemli nokta, Dünya Bankası ve benzeri kuruluşlar tarafindan yapılan plan ve programlarda ve bunlara dayanarak gerçekleştirilen uygulamalarda temel alınan verilerde kalkınmış, sanayileşmiş ülkelerin verilerinden yola çıkılarak başarının ya da başarısızlığın tanımlanmasidir.

İnsan ihtiyaçlarının sınırsız fakat mevcut kaynakların sinırlı olduğu temel tespitinden yola çıkılarak, bugünün kaynaklarını gelecek nesilleri de düşünerek planlı bir şekilde kullanma savının aynı zamanda dünyadaki mevcut kaynakların yarısından fazlasını tüketen ülkeler tarafindan ileri sürüldügü de bilinen bir gerçektir (De Rivero, 2003). Ayrıca, üretilen programların ve yapılan yatırımların karşılığ1 olarak elde edilen başarıların birbirini tam olarak karşılayıp karşılamadığ ya da sürdürülebilir olup olmadığı da açık ve net değildir.

Escobar'a göre (1995), klasik kalkınma modelleri ve kuramlarından farklı olarak çevre ve insanı merkezine alan ama aynı zamanda küresel ekonomik dalgalanmaları ve piyasa değerlerini de göz ardı etmeyen bir yaklaşım olarak düşünüldüğünde sürdürülebilir kalkınma, kendisinden önceki yaklaşımların eksikliklerini tamamlayan bir revizyon olarak görülebilir. Yaşama sayg1 duymak, insanoğlunun yaşam kalitesini artırmak, yeryüzündeki yaşamın çeşitliliğini korumak, yenilenemeyen kaynakların tüketimini en aza indirmek, yeryüzünün taşıma kapasitesinin üzerine çımamak, alışkanlıklarımızı değiştirmek, herkesin kendi yöresine sahip çıkmasına olanak tanımak, kalkınma ve çevreyi bütüncül politikalar çerçevesinde ele almak gibi temel ilkeler çevresinde ilk defa Bruntland Raporu'nda sistemli bir şekilde ifade edilen sürdürülebilir kalkınmayı postkalkınmacı bir yaklaşım olarak görmek çok da yanlış olmaz.

Bu noktada, Arturo Escobar'in (1995) postkalkınmacı kuram ve uygulamalara ilişkin eleştirilerine değinmekte yarar vardır. Özellikle, bu çalışmanın temel çıkış noktası ile Escobar'ın görüşleri arasında paralellik bulunmaktadir.

Escobar'in antropolojide post-kalkınma eleştirisi kalkınma çalışmalarında sosyal hareketlerin ve kalkınma seçeneklerinin anlaşılmasında ve yorumlanmasında bir hareket noktası teşkil etmektedir. Escobar'ın üzerinde durduğu temel kavramsal çerçeve, kalkınmanın kuramsallaştırılması, bir tür mücadeleci kalkınmanın 
yorumlanmasıdır. Ona göre (1995), Batı kalkınması özellikle İkinci Dünya Savaşı sırasında, Üçüncü Dünyadaki toplumsal gerçeklik görüş ve tasarımlarının inşasında birçok çarpıtılmış veriyi kullanmıştır. Böylece başka türden bir kalkınma modeli arayışı, katılımcı kalkınma, sosyalist kalkınma gibi görece birbirinden farklı fakat Batı Merkezli birçok kalkınma modeli Üçüncü Dünya'ya dayatılmıştır.

Escobar'in bakışı, Edward Said'in Oryantalizm kuramını takip etmektedir. Batı kurumları tarafindan kalkınmanın planlanması ve bilginin üretimi, Üçüncü Dünya ülkeleri ve bölgeleri için kaçınılması güç gerçekler olarak görülmüştür. $\mathrm{Bu}$ hâkimiyet, yeniden inşa ve otorite kurma üç aşamada ilerlemiştir (Escobar, 1995: 157):

1. Üçüncü Dünya'nın sorunlarının tahlili, belirgin dış müdahaleler yoluyla yapılandırılmak suretiyle yeniden tanımlanmıştır.

2. Kalkınmanın uzmanlaştırılması ve bu çerçevede siyasi sorunların yeniden inşası, tarafsız bilimsel terimlerin içeriklerinin (yoksulluk göstergeleri gibi) ters yüz edilmesini beraberinde getirmiştir.

3. Kalkınmanın kurumsallaştırılması, sorunların tahlil edilmesi ve güç odaklarının ve bilginin yeni saha ağlarının biçimlendirilmesi, davranışların ve gerçekliklerin kesinleştirilmesi (kırsal kalkınma söyleminde, üretim ya da bozulma her bir kuralda aynıdır).

Escobar’a (1995) göre, İkinci Dünya Savaşı sonrası dönemde kalkınmanın uzmanlık alanı haline gelmesi, yeni akademik programlar, konferanslar, danışmanlık vasıtasıyla yerel kapasiteyi güçlendirme hizmetleri yoluyla bir araştırma verisi olarak Üçüncü Dünya anonimleştirilmiştir. Ayrıca yoksulluk, cehalet ve açlık, devlet memurları, uzmanlar ve planlamacılar için yeni bir endüstri alanı açması bakımından imkân yaratmıştır.

Yeni kalkınma söylemi, sömürgecilikten daha ince ve kurnaz bir üslupla Üçüncü Dünya'nın az gelişmişliğini yaratır. Evrensel Batı paradigmaları, Batı coğrafyacıları, antropologlar ve diğer sosyal bilimciler suça ortaktırlar. Üçüncü Dünya ikincil, kontrol altında ve asimile edilmiş bir öteki olarak kalkınmanın çoğulcu düşüncesi ve Batı jeopolitik imgelemi tarafından tasarlanmıştır (Escobar, 1995).

Escobar'a göre (1995), yeni kalkınma ya da postkalkınma yaklaşımlarından biri olan sürdürülebilir kalkınma retoriği ya da söylemi de doğal kaynakların korunması ve sanayileşme sürecini tamamlamış olan ülkelerin ihtiyaçlarının dengelenmesi için bağımsız değişkenlerin kontrol altına alınmasını şart koşmaktadır. Uluslararası yardım fonlarından aktarilan paralar ya da teknoloji ile bağımsız değişken olarak görülen gelişmekte olan ya da geri kalmış ülkelerin kontrol altına alınması için gerekli düzenlemelerin yapılması esası burada işlemektedir.

Yerel bilgiye verilen değerin artması, çoğulculuk ve katılımcilık temelli eylem politikaları uluslararası şirketleri ve kurumları harekete geçirmiştir. Bu sürece paralel olarak, son y1llarda antropologlar uluslararası kalkınma projelerinde ve yardım programlarında artan önemde yer almaya başlamışlardır. 1974'te ilk defa Dünya Bankası tarafindan tam zamanlı çalışacak bir antropologun istihdam edilmesi de bu sürecin bir parças1 olarak görülmelidir (Nenda ve Warms, 2002).

Bugün yüzlerce antropolog, sosyolog, siyaset bilimci kalkınma projelerinin tasarlanması ve uygulaması için çeşitli kurum ve kuruluşların bünyesinde katkı sağlamaktadır. Antropologlar kalkınmanın kültürel ve sosyal organizasyonlara verilen önem sonucunda daha kalıcı başarılara imza atılabileceğini de göstermiş durumdadırlar. Antropolojik katkı özellikle yerel yapıya ve yaşam biçimlerine uygun ve kabul edilebilir ciddi eylem politikalarının üretilmesi, şehirleşme, kırsal kalkınma, eğitim ve yeniden yerleşim programlarının başarısı için kritik önemdedir.

Bunoktada,Escobar'ın söylemiönplana çıkmaktadır. Ona göre, antropologlar kapitalizmin yeniden ve daha inceltilmiş paradigmalarının yeniden üretimine katkıda bulunmaktadır. Sürdürülebilir kalkınma yaklaşımı ise daha fazla yerel bilgi, katılımcıllık, çoğulculuk ve yönetişim gerektirdiğinden antropologların katkısına oldukça açı, hatta muhtaç bir söylemdir (Escobar, 1995).

Diğer yandan, sürdürülebilir kalkınmanın belirli bir tanımı olmadığı, onun daha çok ilkeler bütünü olduğu yaygin kabul gören bir görüştür. Bir önceki başlıkta kısaca bu ilkelerin ne şekilde ortaya çıtı̆̆ı özetlenmeye çalışılmıştır.

Bilindiği gibi, Rio Zirvesi sürdürülebilir kalkınmanın üç önemli unsurunu aşağıdaki gibi tanımlamıştır (Çevre Bakanlığ1, 2002: 19):

1. Sosyal İlerleme: Adalet, sosyal birliktelik, sosyal hareket, katılım, kültürel kimlik;

2. Ekonomik Büyüme: Gelişme, verimlilik, denge;

3. Çevresel Koruma: İnsanlar için sağlıklı bir çevre, yenilenebilir doğal kaynakların akılc1 kullanımı, yenilenmesi mümkün olmayan doğal kaynakların korunması.

Bugün, söz konusu ilkelerin devlet politikalarına yansıdığ 1 bilinen bir gerçektir. Fakat gerek ülkelerin kalkınma politikalarının uygulama aşamasında karşılaştıkları aksaklıklar ya da zafiyetler gerekse de ilkelerin genel anlamda içeriksiz oluşundan kaynaklanan tutarsızlıklar göz önüne alındığında bu ilkelerin gerçekleştirilebilirliğive bunun ötesinde sürdürülebilirliği 
sorusu ilk günkü gibi tazeliğini korumaktadır.

Bir başka önemli konu ise, bu çalışmanın da ana araştırma konusunu ve merkez sorununu oluşturmaktadır. Bilindiği gibi son yıllarda, uluslararas1 şirketler büyük fonlarını sosyal ve çevresel kalkınma programlarına ve projelerine ayırmaktadır. Dünyanın belli başlı petrol, doğalgaz ve maden şirketleri (Shell, BP, Rio Tinto vb.) bu tür yatırım faaliyetlerinde baş1 çekmektedir. Dünya Bankası'na bağlı Uluslararası Mali İş birliği (IFC) çatısı altında ve onun yayınlamış olduğu IFC Çevresel ve Sosyal Rehberi çerçevesinde çalışan bankalar büyük çaplı kredi talebinde bulunan şirketlere düşük faizli kredi karşıllı̆ında birçok sosyal ve çevresel yükümlülük dayatmaktadır. Şirketler ise, ucuz kredi karşıllığında bu yükümlülükleri kabul etmektedir. $\mathrm{Bu}$ durum, devletlerin oluşturduğu politikalar ya da uluslararası kurumların yardım programlarının şekil ve içeriğinden ayrı bir durum olarak görülmelidir.

Bilindiği gibi, Dünya Bankası'nın bir alt birimi olan IFC 1956 yilında kurulmuştur. İlgili birim, gelişmekte olan ülkelerde özel sektöre kredi açmak ve özel sektörün gelişmesini sağlamak ile görevlidir. Türkiye de bu kuruma kurulduğu yil katılmıstır ve toplam sermaye içinde $\% 0,6$ paya sahiptir (IFC, 2006).

IFC Standartları Rehber Kitapçı̆̆ı, açık olarak sürdürülebilir kalkınma yaklaşımını temel alır. Buradan hareketle sürdürülebilir kalkınma yaklaşımının egemen ve dayatılan bir paradigma olduğu sonucu çıkartılabilir. IFC'nin yayınlamış olduğu rehber, şirketler tarafindan yapilması ve uyulması gereken temel kural ve ilkeleri içeren bir sosyal ve çevresel taahhüt kitapçı̆̆ıdır. IFC'ye bağlı bankalar kredi verdikleri şirketleri denetlemek için bünyelerinde birçok uzman danışman çalıştırmakta, kredi verilen şirketlerden benzeri uzman ve danışmanlarla çalışmalarını istemekte, bunun dışında yazılı ve takvime dayalı bir çalışma talep etmektedir (IFC, 2006).

Buna kısaca, farklı türden bir kalkınma şablonu denilebilir. $\mathrm{Bu}$ şablona göre, IFC standartları çerçevesinde kredi alan şirketlerin çalışma yaptıkları bölgede çevresel ve sosyal anlamda sürdürülebilir iyileştirmeler yapmaları, yapacakları çalışmalar ile ilgili gelecekte oluşabilecek sosyal, çevresel etkileri belirleyip, bu etkileri en aza indirmek için önleyici faaliyetleri organize edip uygulamaya koymaları beklenmektedir (IFC, 2006).

IFC Çevresel ve Sosyal Sürdürülebilirlik Üzerine Politikası'nda (2006), sosyal ve çevresel standartların kapsamlı birtakım olarak uygulamaya konmasının sosyal ve çevresel sürdürülebilirliğin sağlanabilmesinin en önemli basamağı olduğu ifade edilmektedir. Ayrıca, IFC çevresel ve sosyal sürdürülebilirlik taahhüdünü uygulamaya koymak için atılması gereken adımları bu politika ile belirlediğini ifşa etmektedir.
İlgili belgede, IFC'nin misyonunun gelişmekte olan ülkelerde sürdürülebilir özel sektör gelişimini teşvik etmek, yoksulluğun azaltılmasına ve insanların yaşamlarını iyileştirmesine yardımcı olmak olduğu ifade edilmektedir. IFC, sürdürülebilir özel yatırıma dayalı ekonomik büyüme, yoksulluğun azaltılması açısından son derece önemli olduğuna inanmaktadır (IFC, 2006).

Uluslararası şirketlerin uymakla yükümlü oldukları çevresel ve sosyal sürdürülebilirlik ölçütlerinin ise uygulamada ne kadar başarıya ulaştığı ise ayrı bir konudur. Özel şirketlerin kâr amaçlı yatırımlara yöneldiklerini ve bu tür sosyal ve çevresel projeleri zoraki uygulamaya koydukları ilk elden söylenebilir. Diğer yandan, uluslararası denetleme mekanizmaları sayesinde sürdürülebilirliği kuşkulu kimi projelere imza attıkları da gözden kaçırılmamalıdır. Özellikle, devlet desteği ve güvencesi altında gerçekleştirilen büyük ölçekli projeler söz konusu olduğunda özel şirketlerin daha dikkatli oldukları ve proje sahipleri ve paydaşlarının sosyal sorumluluk projelerine ciddi anlamda eğildikleri görülmektedir.

\section{Kaynakça}

Akçalı, R. (1995). Sürdürülebilir Kalkınma, Yeni Türkiye Dergisi, Cevre Özel Sayısı, 39, Ankara: Yeni Türkiye.

Arce, A., ve Long, N. (2000). Reconfiguring Modernity and Development from an Anthropological Perspective, A. Arce ve N. Long (Ed.) içinde, Anthropology, Development and Modernities: Exploring Discourses, Counter-Tendencies and Violence (s. 1-30), London: Routledge.

Barry, J. (2007). Environmental and Social Theory, Second Edition, London: Routledge.

Bates, D.G. (1996). Cultural Anthropology, USA: Allyn \& Bacon.

Bendix, R. (1995). Sanayileşme, Modernleşme ve Kalkınma, I. Sezal (Ed.) içinde, Sosyoloji Yą̧lar, 3. Baskı (s. 161-169), Bursa: Ekin.

Bıçkı, D., ve Kaya, Y. (2006). Sürdürülebilirlik Argümanı ve Derin Ekolojik İtiraz, Gaqui Üniversitesi İktisadi ve İdari Bilimler Fakültesi Dergisi, 8(3), 231-249.

Booth, D. (1994). Rethinking Social Development: Theory, Research and Practice, Essex: Longman Scientific \& Technical.

Clark, J. (1996). Kalk.ınmanın Demokratikleşmesi, (S. Ural, çev.) Ankara: TÇV.

Cleveland, D. (2000). Globalization and Anthropology: Expanding the Options, Human Organization, 59(3), 370-374.

Çevre Bakanlığ1 (2002). Sürdürülebilir Dünya Kalk.mma Zirvesi Türkìve Ulusal Raporu (Taslak), Temmuz 2002.

De Rivero, O. (2003). Kalkınma Efsanesi, (Ö. Karakurt, çev.), İstanbul: Çitlenbik.

Ekici, B. (2002). Sürdürülebilir Kalkınma Anlayış Bağlamında Yerel Gündem 21 Calssmalarmın Önemi ve İslevleri, Yayımlanmamış Doktora Tezi, Bursa Uludağ Üniversitesi Sosyal Bilimler Enstitüsü, Bursa, Türkiye. 
Sezener |Antropoloji 38 (2019), 20-30

Escobar, A. (1991). Anthropology and the development encounter: the making and marketing of development anthropology, American Ethnologist, 18(4), 658- 682. DOI: 10.1525/ ae.1991.18.4.02a00020

Escobar, A. (1995). Encountering Development: The Making and Unmaking of the Third World, Princeton: Princeton University.

Estes, R. J. (1993). Toward Sustainable Development: From Theory to Praxis, Social Development Issues, 15(3), 1-29.

Frazier, J. G. (1997). Sustainable development: modern Elixir or sack dress?, Environmental Conservation, 24(2), 182-193. DOI: $10.1017 /$ S0376892997000246

Gardner, K., ve Lewis D. (1996). Anthropology, Development and the Post-Modern Challenge, London: Pluto.

Gökdayı, İ. (1997). Cevrenin Geleceği: Yaklaşımlar ve Politikalar, Ankara: TÇV.

Green, E. C. (Ed.) (1986). Practicing Development Anthropology, Boulder CO: Westview.

International Finance Corporation. (2006). Policy on Social and Environmental Sustainability, Washington: IFC.

Kates, R. W. (Ed.) (2001). Sustainability science, Science, 292(5517), 641-642. DOI: $10.1126 /$ science.1059386

Keleş, R., ve Hamamc1, C. (2002). Çevrebilim, Ankara: İmge.

Kılıç, S. (2006). Yeni Toplumsal ve Ekonomik Arayışlar Sürecinde Sürdürülebilir Kalkınma, Gazi Üniversitesi İktisadi ve İdari Bilimler Fakültesi Dergisi, 8(2), 81-101.

Kottak, C. P. (2004). An Anthropological Take on Sustainable Development: A Comparative Study of Change, Human Organization, 63(4), 501-510. DOI: $10.17730 /$ humo.63.4.g35k2c3t0tpyqgh3

Nenda, S., ve Richard L. W. (2002). Cultural Anthropology, Seventh Edition, USA: Wadsworth.

O'Connor, J. (1991). The Second Contradiction of Capitalism: Causes and Consequences, Capitalism, Nature, Socialism, USA: Pamphlet 7.

Özbudun, S., ve Balk1 Ş. (2005). Antropoloji: Kuramlar/Kuramcilar, Ankara: Dipnot.

Tolunay, A., ve Akyol, A. (2006). Kalkınma ve Kırsal Kalkınma: Temel Kavramlar ve Tanımlar, SDÜ Orman Fakültesi Dergisi, 7(2), 116-127. DOI: $\underline{10.18182 / \text { tjf.14685 }}$

Türkay, M. (1995). Gelişme: Kavramsal Köken ve Yorumlar, T. İşgüden vd. (Ed.) içinde, Gelişme İktisadr, İstanbul: Beta.

Türkiye Çevre Vakfı. (1991). Sürdürülebilir Kalkınma El Kitabı, Ankara: TÇV Yay.

UN Environment Programme (UNEP) (1981). In Defence of the Earth: the basic texts on environment, Nairobi: UNDP.

World Bank (2002). World Development Report 2002: Building Institutions for Markets, USA: World Bank.

Worldwatch Enstitüsü (1996). Dünyann Durumu 1996. Sürdürülebilir bir Toplum İçin Worldwatch Enstitüsü Raporu, (S. Gül, çev.), Ankara: TÜBİTAK/TEMA Vakfı Yay.

Worldwatch Enstitüsü (2005). Dünyann Durumu 2005: Sürdürülebilir bir Toplum için Worldwatch Istitute Raporu, (A. Başç1, çev.), İstanbul: TEMA Vakf1 Yay.
Yavilioğlu, C. (2002). Kalkınmanın Anlambilimsel Tarihi ve Kavramsal Kökenleri, CÜ İktisadi ve İdari Bilimler Dergisi, 3(1), 59-77. 